\title{
Analysis of Factors Related to Neonatal Mortality in the Hulu Sungai Selatan Regency in 2018
}

\author{
Mahrita *, Husaini ${ }^{*}$, Triawanti ${ }^{* *}$, Roselina Panghiyangani ${ }^{* * *}$, Meitria Syahadatina Noor ${ }^{* * * * *}$ \\ ${ }^{*}$ Master of Public Health, Faculty of Medicine, Lambung Mangkurat University, Indonesia \\ ** Department of Biochemistry, Faculty of Medicine, Lambung Mangkurat University, Indonesia \\ **** Department of Biomedicine, Faculty of Medicine, Lambung Mangkurat University, Indonesia \\ ${ }^{* * * * *}$ Department of Public Health, Faculty of Medicine, Lambung Mangkurat University, Indonesia \\ DOI: 10.29322/IJSRP.10.08.2020.p104126 \\ http://dx.doi.org/10.29322/IJSRP.10.08.2020.p104126
}

\begin{abstract}
Neonatal mortality is one of the determinants of children's health and well-being. SDGs are targeting to reduce neonatal mortality at least up to $12 / 1000$ live births. The neonatal mortality rate in the Hulu Sungai Selatan Regency in 2018 is the highest in the South Kalimantan Province of 18/ 1000 live births. This research aims to analyze the relationship between maternal age, parity, gestational age, pregnancy complications, childbirth complications, infant birth weight, asphyxia, congenital abnormalities, and birth attendants with neonatal mortality in the Hulu Sungai Selatan Regency in 2018. This study was an observational analytic study with a case-control design conducted in Hulu Sungai Selatan Regency. The sample of the study was 41 cases and 43 controls. The result showed that maternal age (p; $0.486>0.05)$, parity $(\mathrm{p} ; 0.775>0.05)$, gestational age $(\mathrm{p} ; 0.000<0.05$, OR $=23.563)$, pregnancy complications $(\mathrm{p}$; $0.001<0.05$, OR $=0.154)$, childbirth complications $(\mathrm{p} ; 0.002$ $<0.05, \mathrm{OR}=6.660)$, infant birth weight $(\mathrm{p} ; 0.000<0.05, \mathrm{OR}=$ 23.560 ), asphyxia ( $p ; 0.000<0,05$. OR $=11,893)$, congenital abnormalities ( $;$; $0.011<0.05$ ), and birth attendants (p; $0.713>0.05)$. The logistic regression test results showed a significant gestational age $(p=0.001$, Exp. $B=29.197)$. There is a significant relationship between gestational age, pregnancy complications, childbirth complications, infant birth weight, asphyxia, and congenital abnormalities with neonatal mortality in the Hulu Sungai Selatan Regency in 2018.
\end{abstract}

Index Terms- maternal, infant, neonatal mortality

\section{INTRODUCTION}

$I_{n=m}^{n}$ ncreasing the degree of health is a part which is not inseparable from the development of national who must be continuously pursued by the government. In addition, an indicator that also is used as a benchmark measuring the progress of the results of the development in the field of health is the number of neonatal mortality (Sihmawati et al., 2018).

According to the Demographic and Health Survey (2017), the neonatal mortality rate (NMR) in Indonesia is 15 per 1,000 births alive. According to Bappenas in 2016, neonatal mortality was one of the determinants of children's health and well-being. Based on the data from the Profile of South Kalimantan Provincial
Health Office in 2018, NMR at the Hulu Sungai Selatan Regency amounted 17/1000 Birth of Life and is the highest NMR compared to other regencies.

According to Achadi (2019), as many as $47 \%$ of deaths under five is the death of neonatal relates closely to the quality of service delivery and handling of infants newly born that is less than optimal immediately after birth and a few days the first after the birth. Three- quarters of neonatal deaths occur in the first week, and $40 \%$ die within the first 24 hours. The major cause death of a newborn in the year 2016 is premature, complications related to childbirth (asphyxia or difficulty breathing when born), infections and birth defects.

Based on the data, the ministry of health is known that amounted to $46.2 \%$ mortality infant caused by problems neonatal, namely asphyxia and low birth weight (Yuwono SR, 2014). Asphyxia is the cause of death neonatal most high (Nurjanah, 2018). According to Tarigan et al. (2017), there are two kinds of causes of death of the baby that is the cause of endogenous and exogenous. Death infant or neonatal endogenous is the death of infants that occurred in the months first after birth, and are generally caused by factors that brought the child since birth, which was obtained from the parents at the time of conception or in the can during pregnancy. While the cause of death of infant exogenous or mortality postneonatal is the death of a baby that occurs after the age of one month until before the age of one year who are affected by the environment outside.

According to research Rachmadiani et al . (2018), which is a risk factor for infant mortality aged 0-28 days in dr. Soebandi Hospital, Jember Regency from the mother factor. There is a relationship significantly between the ages of pregnancy with the death of the baby, the results of the study showed that the age of gestation $<37$ weeks of experiencing the risk of death as much as 2.92 times higher than the age of pregnancy $\geq 37$ weeks. There is a relationship significantly between the age of the mother at the death of the baby, the results of the study showed that the age of the mother $<20$ years and $>35$ years experiencing the risk of death baby as much as 4.51 times higher than the mother with the age of 20-35 years.

According to Anita Rahayu and Rodiani (2016), trauma for newborn injuries associated with macrosomia is shoulder dystocia, 
clavicular fractures, brachial plexus injury, decreased APGAR score for 5 minutes, prolonged labour intervals, and the need for emergency treatment for macrosomial babies.

According to Oktarina et al. (2017), there is a relationship of parity to neonatal death. Pregnant women giving birth to first to third babies/more have 5.5 times the chance of experiencing neonatal death compared to mothers who give birth to second babies. There is a significant relationship between childbirth complications and neonatal death, that complication that occurs in mothers during labor increase the risk of early neonatal death. Mothers who have complications during labour are five times more likely to have a neonate who dies before they reach 7 days of age compared to women who have no complications during labour and delivery complications.

According to research Tarigan et al., (2017) there was a significant relationship between pregnancy complications and infant mortality, the results showed that mothers with pregnancy complications showed that infant mortality in mothers with pregnancy complications was higher $(45.2 \%)$ compared to pregnant women who did not experience complications, as many as $16,6 \%$.

According to research Kurniawan and Melaniani (2018), there is a significant relationship between birth attendants, not health workers and the status of infant mortality, the more babies born are helped not by health workers will increase the chance of 3.67 times the chance of mothers giving birth with the condition of the baby dying.

According to the data of the Office of Health Hulu Sungai Selatan Regency about the neonatal mortality in the year 2017, obtained the data that the number of birth life as many as 3.498 babies, birth-death as many as 38 cases, death of infants aged 028 days (neonatal) as many as 59 babies and death of infants aged 29 11th day of the month (post-neonatal) as many as 24 babies.

The research aims to analyze the age of mother, parity, age of the pregnancy, complications of pregnancy, complications of childbirth, birth weight, asphyxia, abnormal congenital, and attendant birth to neonatal mortality in the Hulu Sungai Selatan Regency in 2018.

\section{RESEARCH METHOD}

This study uses a retrospective approach (case-control). This research located on all the working areas of community health centers in the Hulu Sungai Selatan Regency. There are cases of neonatal mortality based on reports from Health Office of Hulu Sungai Selatan Regency in January to December 2018, which showed that the neonatal mortality (infants aged 0-28 days) as many as 65 babies. The samples in the study are drawn by porpusive sampling. The case is the data about the death of infants aged 0-28 days. The controls are set based on the case for a single control (1: 1).

\section{FINDINGS}

Table 1. Relationship between Independent Variables and Neonatal Mortality in Hulu Sungai Selatan Regency in 2018

\begin{tabular}{|c|c|c|c|c|c|c|c|}
\hline \multirow{3}{*}{$\begin{array}{l}\text { Independent } \\
\text { Variables }\end{array}$} & \multicolumn{4}{|c|}{ Neonatal Mortality } & \multirow{2}{*}{$\begin{array}{l}\text { Tot } \\
\text { al }\end{array}$} & \multirow{3}{*}{$\begin{array}{l}p- \\
\text { value }\end{array}$} & OR \\
\hline & \multicolumn{2}{|c|}{ Yes } & \multicolumn{2}{|c|}{ No } & & & \\
\hline & $\mathbf{n}$ & $\%$ & $\mathbf{n}$ & $\%$ & & & \\
\hline Mother age & & & & & & 0.486 & \\
\hline $\begin{array}{l}<20 \text { years } \\
\text { old or } \\
>35 \text { years old }\end{array}$ & 8 & 61.5 & 5 & 38.5 & 13 & & \\
\hline $20-35$ years old & 33 & 46.5 & 38 & 53.5 & 71 & & \\
\hline Mother parity & & & & & & & \\
\hline $\begin{array}{c}1 \text { or }> \\
3 \text { children }\end{array}$ & 14 & 45.2 & 17 & 54.8 & 31 & 0.775 & \\
\hline $2-3$ children & 27 & 50.9 & 26 & 49.1 & 53 & & \\
\hline
\end{tabular}

Age of pregnancy

$\begin{array}{llllllll}<37 \text { weeks or } & 29 & 87.9 & 4 & 12.1 & 33 & 0.000 & 23.56\end{array}$

$>42$ weeks

$\begin{array}{llllll}37-42 \text { weeks } & 12 & 23.5 & 39 & 76.4 & 61\end{array}$

\begin{tabular}{llllllll}
\hline $\begin{array}{l}\text { Pregnancy compl } \\
\text { ications }\end{array}$ & & & & & & & \\
\hline Yes & 20 & 35.1 & 37 & 64.9 & 57 & 0.001 & 0.154 \\
\hline No & 21 & 77.8 & 6 & 22.2 & 27 & & \\
\hline
\end{tabular}

Childbirth

complications

\begin{tabular}{llllllll} 
Yes & 37 & 59.7 & 25 & 40.3 & 62 & 0.002 & 6.660 \\
\hline No & 4 & 18.2 & 18 & 81.8 & 22 & & \\
\hline
\end{tabular}

\begin{tabular}{llllllll}
\hline Birth weight & & & & & & & \\
\hline $\begin{array}{l}<2500 \\
\text { grams or } \\
>4000 \text { grams }\end{array}$ & 31 & 86.1 & 5 & 13.9 & 36 & 0.000 & 23.56 \\
\hline $\begin{array}{l}2500-4000 \\
\text { grams }\end{array}$ & 10 & 20.8 & 38 & 79.2 & 48 & & \\
\hline
\end{tabular}

Asphyxia

\begin{tabular}{lccccccc} 
Yes & 27 & 81.8 & 6 & 18.2 & 33 & 0.000 & 11.89 \\
\hline No & 14 & 27.5 & 37 & 72.5 & 51 & &
\end{tabular}

\begin{tabular}{llllccc}
\hline $\begin{array}{l}\text { Congenital abno } \\
\text { rmalities }\end{array}$ & & & & & & \\
\hline Yes & 6 & 100 & 0 & 0 & 6 & 0.011 \\
\hline No & 35 & 44.9 & 43 & 55.1 & 78 & \\
\hline Birth attendants & & & & & & \\
\hline $\begin{array}{c}\text { Non-Health } \\
\text { Workers }\end{array}$ & 3 & 37.5 & 5 & 62.5 & 8 & 0.713 \\
\hline Health workers & 38 & 50.0 & 38 & 50.0 & 76 & \\
\hline
\end{tabular}


Table 2. Multivariate Analysis Results

\begin{tabular}{lccc}
\hline Independent Variable & $\begin{array}{c}\boldsymbol{p} \text { - } \\
\text { value }\end{array}$ & OR & $\mathbf{9 5 \%}$ CI \\
\hline Age of Pregnancy & 0.002 & 29.197 & $3.511-242.776$ \\
\hline Birth Weight & 0.004 & 14.601 & $2.378-92.363$ \\
\hline Asphyxia & 0.047 & 5.629 & $1.025-30.909$ \\
\hline Pregnancy Complications & 0.001 & 0.028 & $0.003-0.231$ \\
\hline
\end{tabular}

\section{DISCUSSION}

\section{Relationship between Mother's Age and Neonatal Mortality in Hulu Sungai Selatan Regency}

Chi-square test showed that $\mathrm{p}$-value $=0.486(\mathrm{p}>0.05)$, which means there was no relationship between the age of the mother and neonatal mortality. The results of the analysis of the data in the study have shown that mothers aged 20-35 years are the most neonatal mortality because there are factors of risk like age of pregnancies, complications in pregnancy, and complications in childbirth. It is in line with research by Rachmadiani et al., (2018) that found no significant relationship between the ages of pregnancy with the neonatal mortality, also supported by the research by Tarigan et al. (2017), that there is a relationship that significant between complications of pregnancy with the neonatal mortality and also supported by the research by Oktarina et al., (2017), there is a relationship between complications of childbirth with the neonatal mortality.

Results of the study is consistent with research that is conducted by Batubara and Fitriani (2019), mother age was not associated with risk of death of infants 0-28 days in the regency of Bireuen because the majority of the mother was in the category of 20-35 years which is the ideal age for pregnant and give birth and uterus have been able to carry out its functions with good. At the age of 20-35 years old, the mother understands the factors that can be associated with the death of infants 0-28 days so that steps are taken already perfect.

\section{Relationship between Parity and Neonatal Mortality in Hulu Sungai Selatan Regency}

Chi-square test showed that $p$-value $=0.775(p>0.05)$, which means there was no relationship between parity with the neonatal mortality. According to Manuaba (2007), parity is divided on parity one is not safe, parity 2-3 safe for pregnant and maternity, and parity more than 3 not safe. The number of parity of pregnant women is one of the predisposing factors for premature birth , and the number of parities can affect the health condition of the mother in pregnancy (Riyanti and Legawati, 2018).

The result of the study is consistent with the results of the study conducted by Rofiqoch et al. (2016) that there was no relationship between parity with neonatal mortality because the mother who gave birth at parity 2-3. Parity 2-3 is not a risk factor for neonatal mortality. It is in accordance with studies of other shows that mothers with multiparity and age of mothers ranged between 2034 years old have a risk of the occurrence of the neonatal mortality smaller compared with the mother primiparity aged less than 20 years and multiparous with the age of the mother more than 35 years.

Relationship between Age of Pregnancy and Neonatal Mortality in Hulu Sungai Selatan Regency

Chi-square test showed that $\mathrm{p}$-value $=0.000(\mathrm{p}<0.05)$, which means there was a significant relationship between gestational age and neonatal mortality. Risks at the age of pregnancy less than 37 weeks can result in the occurrence of labour with action midwifery , for example, section cesarean with the presentation of buttocks. Risks at the age of gestation less than 37 weeks at birth preterm can increase the number of death perinatal, as well as with pregnancy more than 42 weeks with the induction of labour, one of the complications is asphyxia neonaturum. Babies born with weight 2000-2500 grams have hope to live more than 97\%, 15002000 grams more than $90 \%$, and $1000-1500$ grams of $65-80 \%$ (Hasanah et al., 2016).

According to Wahyu and Rohani (2017), baby preterm especially who was born in the age of gestation $<32$ weeks, had a risk of death 70 times higher, because they have difficulties in adapting to life on the outside of the uterus due to the immaturity of the system of organs of the body such as the lungs, kidneys, heart and digestive system.

Result of the study is consistent with research conducted by Rachmadiani et al (2018), that there was a relationship between the age of pregnancy with the neonatal mortality. According to Prawirohardjo (2010) the younger the gestational age, the lower the maturity level of the functioning of the infant organs so that the baby will experience many difficulties to live outside the mother's uterus. The more short- term pregnancy, increasingly less perfect growth of organs in the body will be more easily occur complications and increasingly high numbers of death.

Relationship between Complications of Pregnancy and Neonatal Mortality in Hulu Sungai Selatan Regency

Chi-square test showed that $\mathrm{p}$-value $=0.001(\mathrm{p}<0.05)$, which means there was a relationship between complications of pregnancy with the neonatal mortality. Results OR of 0.154 (95\% CI 0.054 to 0.445$)(\mathrm{OR}<1$ or $1 / \mathrm{OR}=6.49)$ showed that the factors which investigated a protective factor, meaning that mothers with complications of pregnancy risk 0.154 times larger or risky to 6.49 times smaller happened neonatal mortality compared with mothers without complications of pregnancy.

The results of this study are in line with the results of the study by Tarigan et al. (2017), that there was a relationship between complications of pregnancy and infant mortality due to mothers with complications of pregnancy the percentage was higher (45.2\%) compared to pregnant women who did not experience complications, as many as $16.6 \%$.

Relationship between Complications of Childbirth and Neonatal Mortality in Hulu Sungai Selatan Regency

Chi-square test showed that $\mathrm{p}$-value $=0.002(\mathrm{p}<0.05)$, which means there is a relationship between childbirth complications and neonatal mortality. The OR result of 6.660 (95\% CI 2.013 to 22.031) case this could mean that mothers with complications of childbirth had a risk of 6.660 times larger neonatal mortality compared with mothers who did not exist complications of 
childbirth.

Labor complications such as premature labor, premature babies often stop breathing for a few moments, called apnea. Often found at 34 weeks gestation (Sondakh, 2013). The results of this study are in line with research conducted by Oktarina et al., 2017, that there is a significant relationship between childbirth complications and neonatal mortality, complications that occur in mothers during labor increase the risk of early neonatal death. Mothers who have complications during labor are 5 times more likely to have a neonate who dies before they reach 7 days of age compared to women who have no complications during labor. The prevalence of neonatal death is twice as high in women who have complications during childbirth.

\section{Relationship between Birth Weight and Neonatal Mortality in Hulu Sungai Selatan Regency}

Chi-square test showed that $\mathrm{p}$-value $=0.000(\mathrm{p}<0.05)$, which means there was a significant relationship between birth weight with neonatal mortality. The OR result of 23.560 (95\% CI 7.286 to 76.187 ), infants with severe birth $<2500$ grams or $>4000$ grams risk 23.560 times larger to neonatal mortality compared with infants who had severe birth 2500-4000 grams.

According to Suryanti (2018), that birth weight is a major risk factor for neonatal mortality. Birth weight is an indicator of the health of newborns; babies with low birth weight ( $<2500$ grams) will have a greater risk of experiencing problems that will come. Low Birth Weight (LBW) is one of the risk factors that have a contribution of 60 to $80 \%$ to all neonatal deaths. Babies with LBW have a 10-20 times greater chance of dying than babies born with sufficient birth weight (Shari et al., 2015).

The results of this study are in line with the results of research conducted by Rachmadiani et al. (2018), body weight has a significant relationship with infant mortality $0-28$ days with an OR value of 9.66, it can be concluded that infants with bodyweight $<2500$ grams have a risk 9.66 times more deaths occur than in babies weighing $\geq 2500$ grams.

\section{Relationship between Asphyxia and Neonatal Mortality in} Hulu Sungai Selatan Regency

Chi-square test showed that $\mathrm{p}$-value $=0.000(\mathrm{p}<0.05)$, which means there is a significant relationship between asphyxia and neonatal mortality. The OR result of 11.893 (95\% CI 4.049 to 34.929), which means that infants with asphyxia (Apgar score <7), has a risk of 11.893 times larger to neonatal mortality compared with infants who did not asphyxia (Apgar scores $\geq 7$ ).

Result of the study is consistent with research conducted by Kusumawardani and Handayani (2018), there was a relationship between infants who suffered asphyxia with the incidence of mortality infant with OR 21.614, which showed that babies who experience asphyxia when the birth has risks 21.614 times larger for the neonatal mortality compared to babies who do not experience asphyxia.

Relationship between Congenital Abnormalities and Neonatal Mortality in Hulu Sungai Selatan Regency

Fisher's Exact test showed that $\mathrm{p}$-value $=0.011(\mathrm{p}<0.05)$, which means that there is a significant relationship between congenital abnormalities and neonatal mortality. The results of this study are in line with the research of Rachmadiani et al. (2018), congenital abnormalities have a significant relationship to neonatal mortality from 0-28 days. Result of the study is also in line with research Kusumawardani and Handayani (2018) that there is a relationship in infants who experience abnormal congenital because of having risk 2.205 times higher for the case of death perinatal compared with infants who did not experience abnormal congenital.

Relationship between Childbirth Attendants and Neonatal Mortality in Hulu Sungai Selatan Regency

Fisher's Exact test showed that $p$-value $=0.713(\mathrm{p}>0.05)$, which means there is a relationship between the childbirth attendant to neonatal mortality.

Result of the study is consistent with research that conducted by Oktarina et al, 2017, there was no relationship between the birth attendant to neonatal mortality, access to skilful labour including doctors and midwives essential to prevent the death of maternal and neonatal. There is no relationship between the childbirth attendant to neonatal mortality because almost the entire pregnant mother has been doing deliveries in the facility services of health, awareness will be the importance of doing deliveries assisted by personnel of health is already high.

\section{The Most Associated Factors with Neonatal Mortality}

The results of the analysis of multivariate of variable age pregnancies, complications of pregnancies, birth weight, and asphyxia obtained results Exp. (B) is the variable age of pregnancy at 29.197, birth weight at 14.601, asphyxia at 5.629 and complications of pregnancy amounted to 0,028 . According to Prawirohardjo (2010), the younger the gestational age, the lower the maturity level of the functioning of the infant's organs so that the infant will experience many difficulties to live outside the mother's uterus. The more short-term pregnancy, increasingly less perfect growth of organs in the body will be more easily occur complications and increasingly high numbers of death.

According to Andriana, (2015), gestational age is in accordance with the weight of the infant and the condition of the fetus which if born is not strong enough to live with the infant's organs that are not yet perfect. Care for infants less months and more months will require more intensive care. Gestational age <37 weeks or > 40 weeks will require more intake, adjustment of body temperature, and other complications of the baby.

The results of this study are in line with research conducted by Azizah and Handayani (2017), that there is a relationship between gestational age and neonatal death, ie mothers whose gestational age $<37$ weeks or $>42$ weeks have an 11.9 times greater risk of neonatal deaths compared to with mothers whose gestational age is $37-42$ weeks with a value of $\mathrm{p}=<0.001(\mathrm{OR}=11.9 ; 95 \% \mathrm{CI}=$ 4.4 - 32). Babies born at $<37$ weeks are called premature babies, preterm labour is a dangerous thing because it has an impact on neonatal death, because the shorter the pregnancy period, the less the growth period of the infant's organs in infants so that it is more susceptible to complications.

\section{CONCLUSION}

1. There is no relationship between mother age and neonatal mortality in the Hulu Sungai Selatan Regency in 2018.

2. There is no relationship between parity and neonatal mortality in the Hulu Sungai Selatan Regency in 2018. 
3. There is a relationship between the age of pregnancy with neonatal mortality in the Hulu Sungai Selatan Regency in 2018.

4. There is a relationship between complications of pregnancy with neonatal mortality in the Hulu Sungai Selatan Regency in 2018.

5. There is a relationship between complications of childbirth with neonatal mortality in the Hulu Sungai Selatan Regency in 2018.

6. There is a relationship between birth weight with neonatal mortality in the Hulu Sungai Selatan Regency in 2018.

7. There is a relationship between asphyxia with neonatal mortality in the Hulu Sungai Selatan Regency in 2018.

8. There is a relationship between congenital abnormalities with neonatal mortality in the Hulu Sungai Selatan Regency in 2018.

9. Not there is a relationship between the childbirth attendant with neonatal mortality in the Hulu Sungai Selatan Regency in 2018.

10. Age of pregnancy is the most dominant variable related with neonatal mortality in the Hulu Sungai Selatan Regency in 2018

\section{REFERENCES}

Achadi EL, (2019), Maternal and Neonatal Death in Indonesia, National Public Health Meeting, ICE, BSD, Tangerang, Banten.

Andriani AR, Sriatmi A., Jati SP, (2015), Factors Causing Infant Mortality in the Work Area of Ngombol's Puskesmas in Purworejo Regency ( Case Study in 2015), Journal of Public Health (e-Journal), 4 (1); 2356-3346.

Azizah I., Handayani OK, (2017), Neonatal Death in Grobogan Regency, Higeia Journal of Public Health Research and Development, 1 (4).

Coal AR, Fitriani, (2019), Factors That Associated With Risk of Death Baby 0-28 Days In Regency Bireuen, Journal of Healthcare Technology and Medicine, 5 (2), University Ubudiyah Indonesia e-ISSN: 2615-109X

Department of Health Regency Hulu Sungai Selatan, Report of Death of Baby in 2017

Hasanah MN, Hariati L., Rasma, (2016), Analysis of Risk Factors for Baby Gender, LBW, Premature Labor, Fractional Amniotic Disease, and Delivery with Neonatal Sepsis at Bahteramas Hospital in Southeast Sulawesi Province in 2016, Scientific Journal of Public Health Students, $1(3) ; 20-28$.

Kurniawan R., \& Melaniani S., (2018), Relationship Parity, Attendant Maternity And Distance Pregnancy With Figures Death Infant In Jawa Timur,
Journal of Biometrics and Population, 7 (2); 113-121, Published: December 31, 2018

Kusumawardani A. \& Handayani S., (2018), Characteristics of Mum and Factors Risk Event of Death Baby in the Regency of Banjarnegara, Journal of Promotion of Health Indonesia, 13 (2).

Reports of IDHS (2017), Figures Death Infant in the province of South Kalimantan, and the Regency Hulu Sungai Selatan.

Nurjanah S., (2018), Source of Power In Management Asphyxia At Home Hospital Operator Services Obstetrics Neonatal Emergency Comprehensive In Regency Demak, Journal of Obstetric, 7 (2), 161-165

Oktarina S., Dawn NA, Yeni, (2017), Model Prediction Genesis Death Neonatal In the Regency Purbolinggo Regency East Lampung province of Lampung, Journal of Science of Public Health, 8 (1): 49-55.

Prawirohardjo S., (2018), Science in Midwifery, edition to four, moulds to five, Publisher: PT. Bina Pustaka Sarwono Prawirohardjo, Jakarta.

Rachmadiani AP, Shodikin MA, Komariah C., (2018), Factors Risk of Death Baby Age 0-28 Day at dr. Soebandi Hospital, Jember Regency, Journal of Agromedicine and Medical Sciences, 4 (2).

Rahayu A., Rodiani, (2016), The Effects of Gestational Diabetes Mellitus on the Birth of Babies Macrosomia, Majority, 5 (4).

Riyanti, Legawati, (2018), Determinant of Neonatal Death at Rsud Sultan Imanudin Pangkalan Bun, Jurnal Surya Medika , 3 (2).

Rofiqoch I., Effendi JS, Dinan S., Bratakoesoema, (2016), Relationship Age Mother, Parity And Attendant Maternity By Death Neonatal In Region Work Puskesmas Regency Banjarnegara year, 2013, Journal of Health Reproduction, 3 (1): 60-68

Sihmawati N.W.D. Sumarjaya I.W., Susilawati M., (2018), Analysis of Neonatal Mortality in Bali Province with Regression Analysis Approach, Mathematical E-Journal, 7 (3), 46-251, ISSN: 2303-1751

Sondakh J.J.S, (2013), Child Midwifery and Newborn Baby Care, Publisher: Erlangga, Jakarta.

Suryanti, (2018), Analysis of Neonatal Death in Batam City, World Journal of Public Health, 7 (3).

Syari M., Serudji J., Mariati U., (2015), The Role of Macronutrient Nutrient Intake for Pregnant Women on Infant Birth Weight in Padang City, Andalas Health Journal. 4 (3).

Tarigan I., U., Afifah T., Simbolon D., (2017), Factors Related to Infant Services in Indonesia: A Multilevel Analysis Approach, Journal of Reproductive Health, 8 (1); 103-118

Wahyuni R., and Rohani S., (2017), Factors Affecting Preterm Labor, Journal of Health Sciences 2 (1).

\section{AUTHORS}

First Author - Mahrita, Master of Public Health, Faculty of Medicine, Lambung Mangkurat University, Indonesia.

Second Author - Husaini. Master of Public Health, Faculty of Medicine, Lambung Mangkurat University, Indonesia.

Third Author - Triawanti, Department of Biochemistry, Faculty of Medicine, Lambung Mangkurat University, Indonesia.

Fourth Author -Roselina Panghiyangani, Department of Biomedicine, Faculty of Medicine, Lambung Mangkurat University, Indonesia.

Fifth Author - Meitria Syahadatina Noor, Department of Public Health, Faculty of Medicine, Lambung Mangkurat University, Indonesia.

Correspondence Author - Mahrita, Master of Public Health, Faculty of Medicine, Lambung Mangkurat University, Indonesia. 